\title{
RESORT BERBASIS KAWASAN KONSERVASI
}

\author{
Gerald Grimaldy $^{1)}$, Sutarki Sutisna ${ }^{2)}$ \\ ${ }^{1)}$ Program Studi S1 Arsitektur, Fakultas Teknik, Universitas Tarumanagara, Gerald.grimaldy@live.com \\ 2) Program Studi S1 Arsitektur, Fakultas Teknik, Universitas Tarumanagara, Sutarkis@gmail.com
}

\begin{abstract}
Abstrak
Di era kota metropolitan yang terus terjadi pembangunan di segala hal yang tak terhentikan ini, dampak negatif mulai bermunculan, daerah-daerah yang harusnya di pertahankan pun habis bila kepentingannya tidak di anggap penting lagi,peraturan tentang daerah konservasi telah dibuat namun tetap tidak memberhentikan laju pengembangan tersebut. Daerah hijau yang menjadi paru-paru kota metropolitan pun sedikit demi sedikit habis menunggu waktu. Selain habisnya paru-paru kota, masyarakat sekitar baru menyadari bahwa pentingnya ruang hijau untuk melegakan pikiran,dengan sifat masyarakat kota yang memiliki mobilitas tinggi terhadap pekerjaaan,kurangnya hiburan untuk refreshing sangatlah kurang. Dari masalahmasalah yang di temukan penulis, proyek ini penulis usulkan,yaitu tentang Daerah Konservasi Berbasis Resort. Konservasi mangrove pun menjadi pilihan utama karena dilihat dari sejarahnya,hutan mangrove yang sebenarnya memiliki banyak manfaat akan habis jika tidak di konservasi yang dapat menghilangkan paru-paru kota ini. Pemecahan masalah terhadap rusaknya ekosistem mangrove pun di akali dengan kegiatan konservasi yang harus di dukung oleh berbagai pihak,dari pemerintah, swasta, masyarakat kota jakarta sampai unit terkecil,yaitu masyarakat daerah sekitar.
\end{abstract}

Kata Kunci: konservasi, mangrove, resort

\begin{abstract}
In the era of metropolitan cities that continue to develop in all things that are unstoppable, negative impacts are starting to emerge, areas that must be maintained are also exhausted if their interests are not considered important anymore, regulations on conservation areas have been made but still do not stop the pace of development that is. Green areas that become the lungs of the metropolitan city are gradually awaiting time. In addition to the exhaustion of the lungs of the city, the surrounding community only realized that the importance of green space to relieve the mind, with the nature of the city people who have high mobility for work, lack of entertainment for refreshing is very lacking. From the problems found by the author, this project the authors propose, namely about the Resort-Based Conservation Area. Mangrove conservation is also the main choice because seen from its history, mangrove forests which actually have many benefits will be used up if they are not in conservation which can eliminate the lungs of this city. The solution to the problem of the destruction of the mangrove ecosystem is also carried out with conservation activities that must be supported by various parties, from the government, the private sector, the people of the city of Jakarta to the smallest units, namely the surrounding community.
\end{abstract}

Keywords: conservation, mangrove, resort

\section{PENDAHULUAN}

Pertambahan populasi penduduk Jakarta menyebabkan kebutuhan akan ruang untuk sarana dan prasarana kota semakin meningkat. Cagar Alam Muara Angke pun dirambah sedikit demi sedikit hingga terjadi alih fungsi lahan yang masif. Akibatnya, dalam kurun waktu 30 tahun sebagian besar kawasan konservasi Muara Angke dengan luas lebih dari $1000 \mathrm{Ha}$ mengalami kerusakan sangat parah dan tidak dapat diselamatkan lagi.

Kawasan konservasi berdasarkan Undang-Undang Nomor 5 Tahun 1990 tentang Konservasi Keanekaragaman Hayati dan Ekosistemnya adalah kawasan yang ditetapkan oleh pemerintah 
sebagai kawasan suaka alam yaitu cagar alam dan suaka margasatwa, kawasan pelestarian alam yaitu taman nasional, taman wisata alam dan taman hutan raya, dan taman buru.

Secara absolut Unit Pelaksana Teknis dalam melakukan pengelolaan kawasan konservasi akan menjaga dan melestarikan keanekaragaman hayati dan ekosistemnya. Secara ilmiah, menjaga dan melestarikan keanekaragamann hayati dan ekosistemnya dilakukan dengan menciptakan kondisi sedemikan rupa sehingga key features kawasan dapat berproses secara alami serta dapat dimonitor dinamikanya, termasuk dengan melakukan tindakan konservasi yang dilakukan.

Dalam pengelolaan kawasan konservasi muncul berbagai permasalahan seperti dihapusnya eselon $\mathrm{V}$ setingkat kepala resort, belum lengkapnya sistem kerja di tingkat resort dan tidak tersedianya anggaran kegiatan di resort mendorong ketidakjelasan pelaksanaan kegiatan minimal yang harus dilaksanakan di tingkat lapangan. Hal ini lebih lanjut mengakibatkan meningkatnya ketidakhadiran staf di lapangan. Ketika lapangan ditinggalkan, maka kawasan seolah-olah menjadi tidak bertuan dan cenderung mengarah ke dalam situasi yang disebut sebagai "open access".

Pada situasi seperti inilah maka intensitas berbagai bentuk gangguan terhadap kawasan semakin meningkat. Gangguan tersebut terwujud dalam berbagai kegiatan ilegal antara lain perambahan, penyerobotan, konflik batas, illegal logging, perburuan satwa, dan pendudukan kawasan oleh berbagai pihak yang tidak bertanggung jawab. Gangguan ini akan semakin meningkat sebagai akibat rendahnya kehadiran staf di lapangan.

Hal inilah yang mendasari perlunya pengelolaan kawasan konservasi berbasis resort sehingga kehadiran staf di lapangan meningkat dan kegiatan-kegiatan minimal yang harus dilaksanakan di tingkat lapangan terlaksana dengan baik dan fungsi pencegahan terhadap meluasnya gangguan hutan tercapai

\section{METODE}

Metode perancangan yang digunakan berupa metode kualitatif melalui literatur buku dan media elektronik dalam mengumpulkan data. Selain itu survey lapangan dilakukan terhadap tapak eksisting dengan hubungannya antara kondisi kawasan di sekitar tapak.

\section{DISKUSI DAN HASIL}

Pembangunan yang terus menerus di seluruh daerah jakarta membuat bagian utara dari Jakarta juga kehabisan tempat. Pembangunan reklamasi pantai untuk memperluas infrastruktur kota Jakarta pun terjadi.

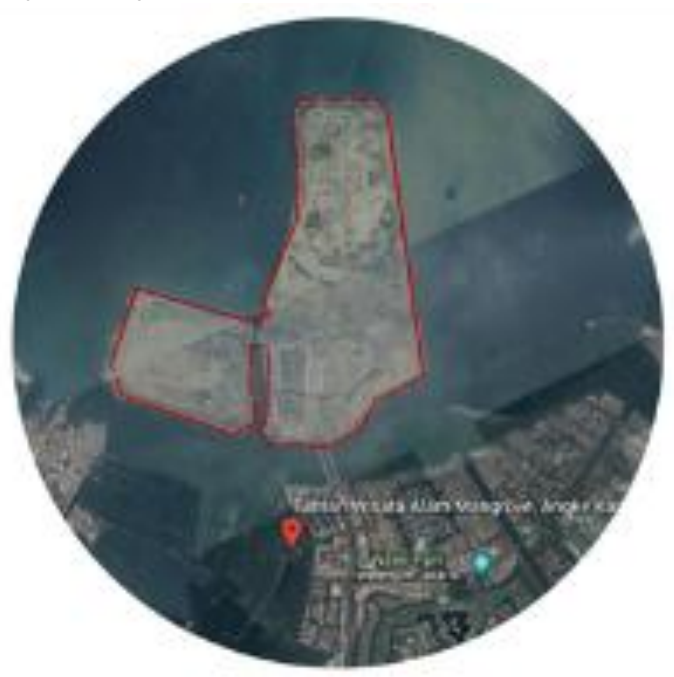

Gambar 1. Daerah Reklamasi Pantai Indah Kapuk Sumber: Google Maps 
Banyaknya jumlah ruang terbuka hijau yang terancam, seharusnya membuat masyarakat lebih sadar untuk lebih melestarikan dan menjaga ruang terbuka hijau yang menjadi ekosistem bagi masyarakat lokal. Dalam hal ini topik wisata ekologi atau ecotourism yang sudah dibahas di atas berprospek untuk menjadi prioritas utama untuk di pertimbangkan di ruang kota metropolitan ini.

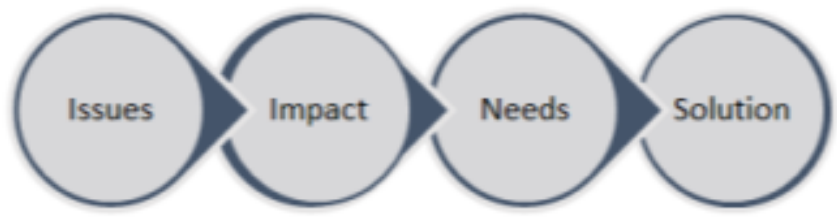
Issues
: Limited land resource.
Impact
: Ruang terbuka hijau terancam.
Needs
: Kebutuhan ruang untuk di bangun tempat wisata.
Solution
: Wisata ekologi sebagai barrier hutan kota.

Gambar 2. Diagram Sintesa Permasalahan

Sumber: Olahan Penulis, 2018

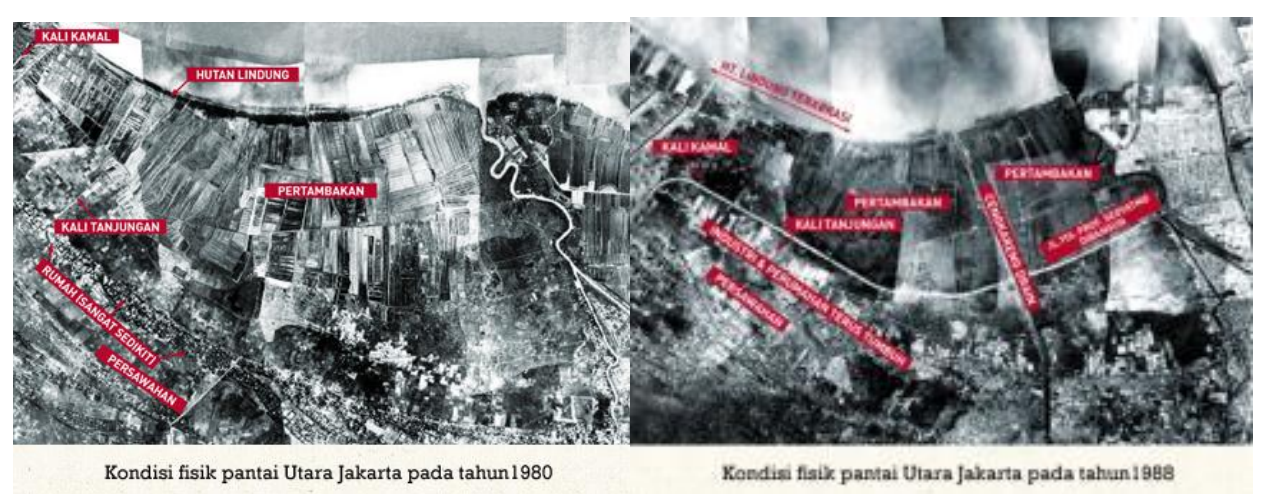

Gambar 3. Perkembangan Kondisi Fisik Pantai Utara Jakarta Sumber: Berbagai Sumber

Pertambahan populasi penduduk Jakarta menyebabkan kebutuhan akan ruang untuk sarana dan prasarana kota semakin meningkat. Cagar Alam Muara Angke pun dirambah sedikit demi sedikit hingga terjadi alih fungsi lahan yang masif. Akibatnya, dalam kurun waktu 30 tahun, sebagian besar kawasan konservasi Muara Angke dengan luas lebih dari $1000 \mathrm{Ha}$ mengalami kerusakan sangat parah dan tidak dapat diselamatkan lagi.

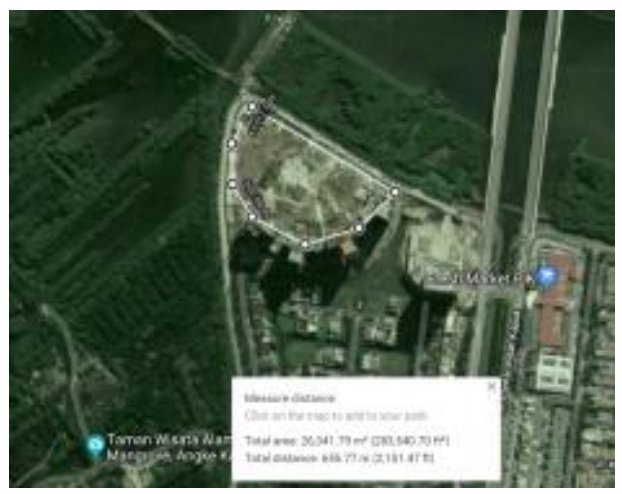

Gambar 4. Lokasi Tapak

Sumber: Olahan Penulis

Tapak yang terletak di daerah Jakarta Utara ini adalah tapak yang menurut penulis strategis untuk di jadikan resort berbasis kawasan konservasi karena bertempat di sebelah hutan 
mangrove yang mulai terkikis habis. Tapak memiliki aksesbilitas dari Jl. Arteri Pluit-Pantai Indah Kapuk dan juga dapat diakses melalui Tol Bandara-Wiyoto Wiyono maupun Tol Kayu Besar. Tapak memiliki akses jalan arteri untuk memasuki daerah sekitar tapak lalu di lanjutkan dengan jalan kolektor sebagai jalan untuk menuju tapak.

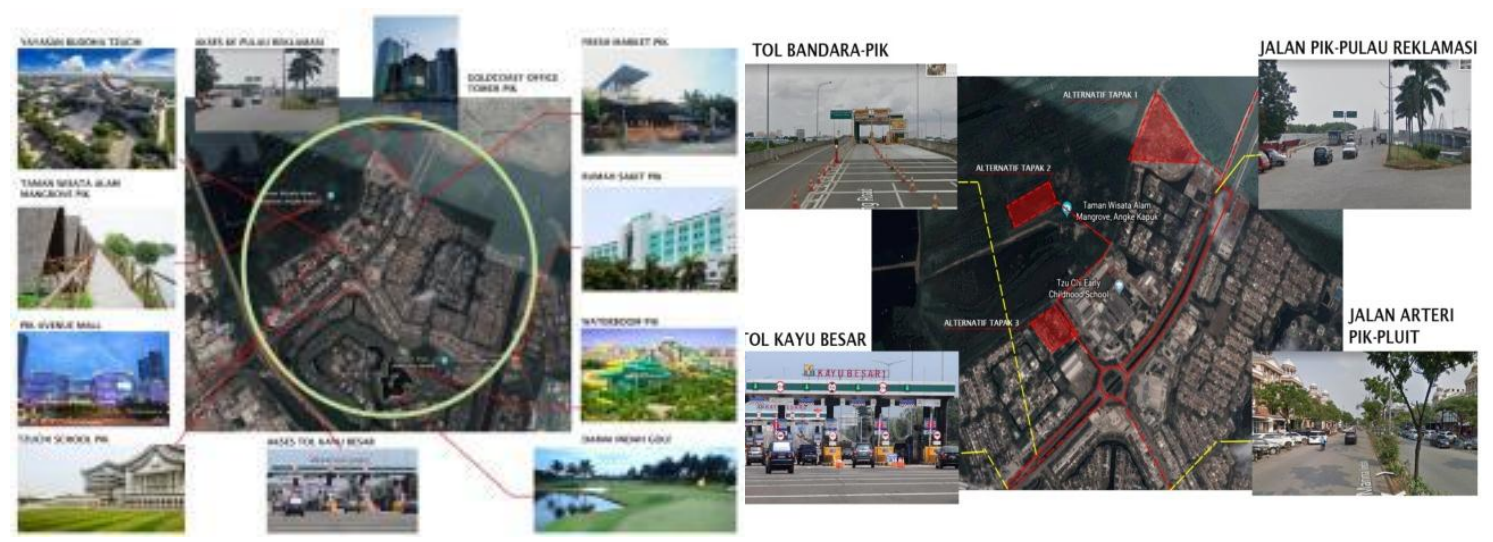

Gambar 5. Aksesibilitas dan Kondisi Sekitar Tapak dan Sumber: Olahan Penulis, 2018

Konsep pengolahan gugus bangunan yang dibuat ini memanfaatkan keadaan sekitar tapak yang pada kondisi eksisting merupakan danau dan taman mangrove. Gubahan massa dibuat melingkar dan di pisah untuk keperluan kamar resort untuk memanfaatkan view sekitar yang menjadi view utama resort ini.

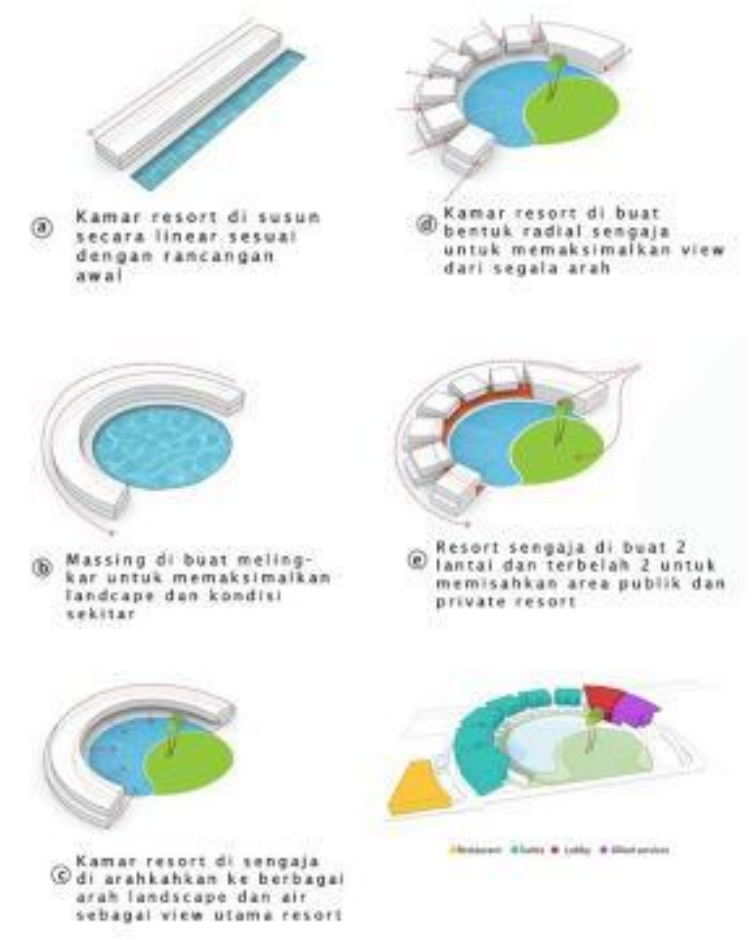

Gambar 6. Proses Gubahan Massa

Sumber: Olahan Penulis, 2018 


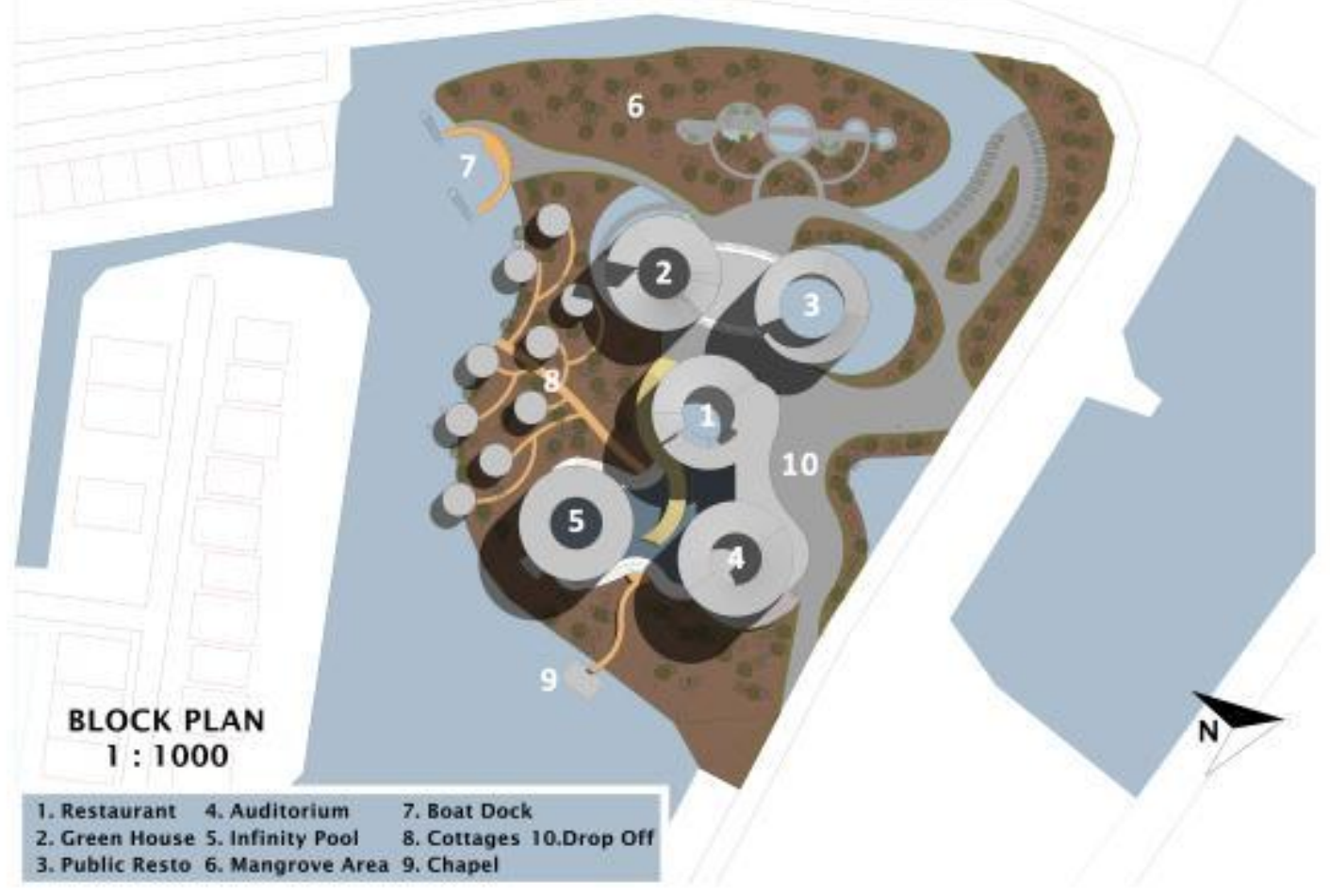

Gambar 7. Block Plan

Sumber: Olahan Penulis, 2018

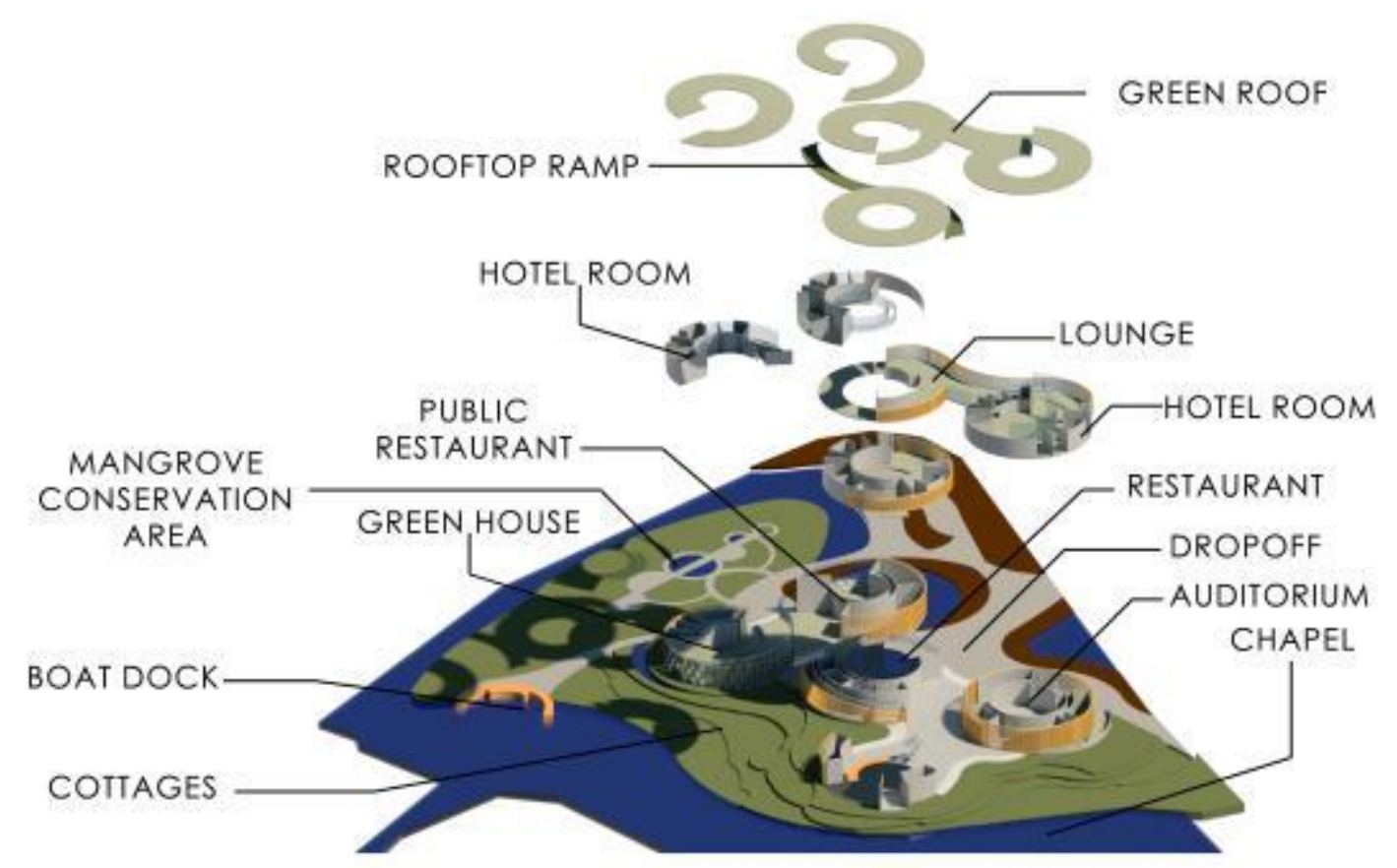

Gambar 8. Exploded Denah

Sumber: Olahan Penulis, 2018 
Konsep tampak bangunan mayoritas menggunakan kisi-kisi. Hal ini merupakan strategi desain yang muncul sebagai hasil adaptasi atas konsep eco green yang menjadi konsep utama resort ini. Upaya desain ini diharapkan pula sebagai ornamen hijau yang dapat menimbulkan kesan eco friendly.

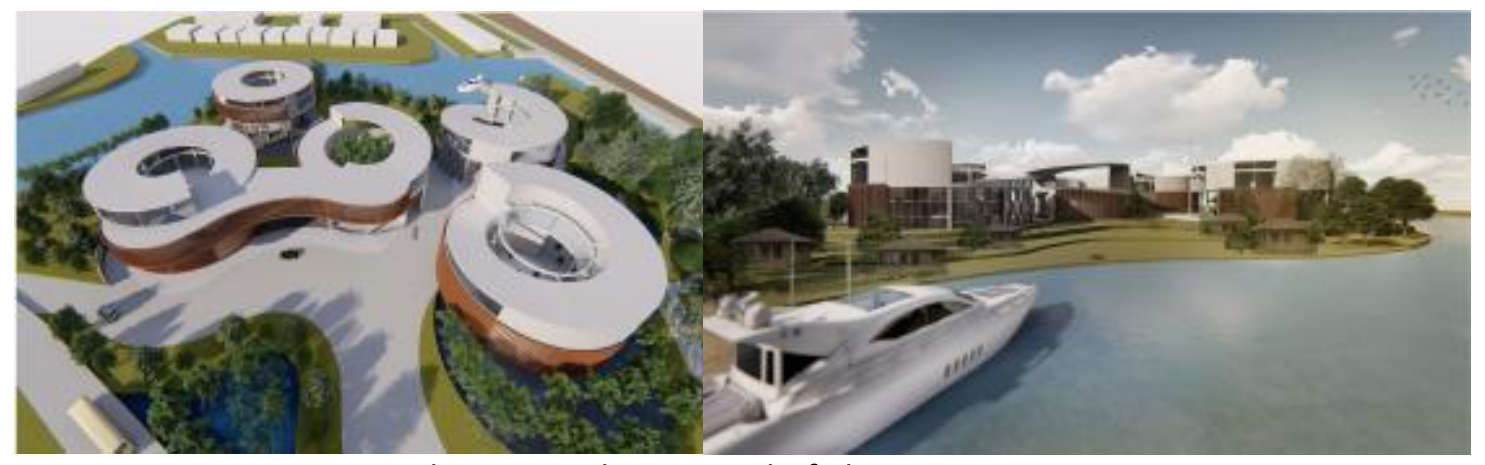

Gambar 9. Gambar Perspektif Eksterior Bangunan Sumber: Olahan Penulis, 2018

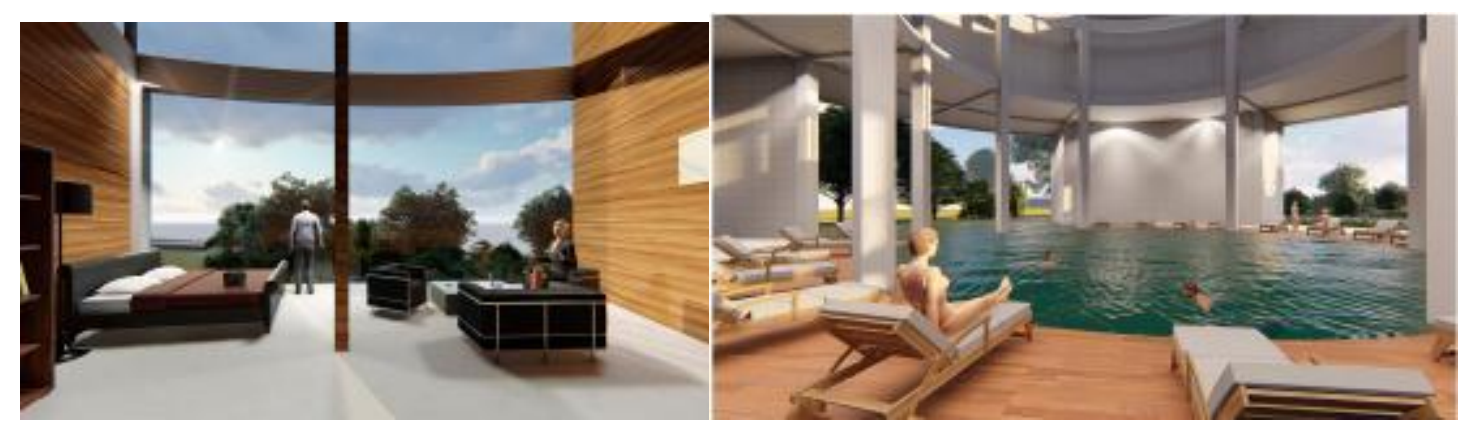

Gambar 10. Gambar Perspektif Interior

Sumber: Olahan Penulis, 2018

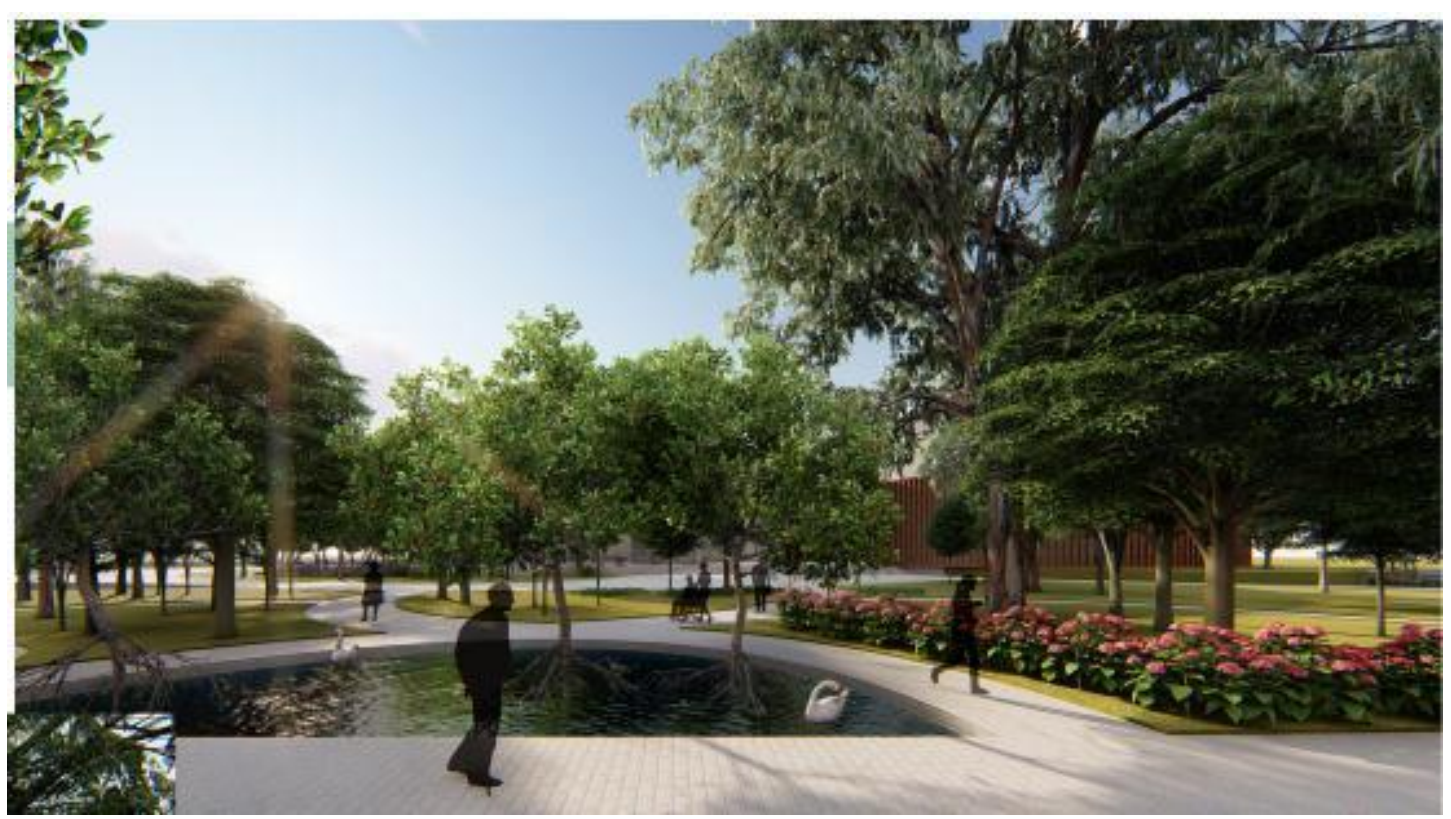

Gambar 11. Suasana Ruang Luar Kompleks Resort

Sumber: Olahan Penulis, 2018 


\section{KESIMPULAN DAN SARAN}

Pengelolaan berbasis resort bukan hanya sekedar meningkatkan kapasitas pengelolaan pada level resort yang didukung dengan sarana dan prasarana serta kepercayaan terhadap pengelolaan anggaran operasional resort. Akan tetapi pengelolaan berbasis resort merupakan suatu alur mekanisme pengelolaan yang saling berkesinambungan baik secara hirarkis maupun secara teknis terhadap berbagai kegiatan yang memberikan keluaran hasil sebagaimana yang telah ditetapkan dalam suatu perencanaan balai.

Perencanaan kegiatan dilaksanakan melalui beberapa diskusi dan penyusunan rencana kegiatan serta inventarisasi kebutuhan penunjang kegiatan resort. Kegiatan yang merupakan operasional resort nantinya diharapkan memadukan antara kegiatan pengamanan hutan, inventarisasi potensi, monitoring, dan kegiatan yang berhubungan dengan pendekatan kemasyarakatan yang dilakukan di masing-masing resort.

Perencanaan kegiatan minimal operasional resort harus mencakup Tiga Pilar Konservasi yaitu perlindungan sistem penyangga kehidupan, pengawetan keanekaragaman hayati dan ekosistemnya, dan pemanfaatan secara lestari. Kegiatan minimal operasional resort ini merupakan tugas minimal yang harus dikerjakan oleh resort yang dijalankan sesuai dengan jabatannya.

Untuk mewujudkan pengelolaan kawasan konservasi berbasis resort dibutuhkan komitmen dari setiap orang yang terlibat dalam merencanakan pengelolaan kawasan konservasi berbasis resort. Komitmen ini harus didukung dalam implementasi penganggaran yang berpihak ke lapangan dan mendukung kerja lapangan (patroli, penjagaan, pemantauan habitat, kunjungan ke desa-desa/kampung terdekat dan sebagainya).

\section{UCAPAN TERIMA KASIH}

Penulis mengucapkan terima kasih kepada Tuhan Yang Maha Esa, dosen pembimbing, keluarga, narasumber dan teman-teman yang membantu dalam proses penyusunan artikel ini.

\section{REFERENSI}

Jan Specht. (2011). Architectural Tourism Building for Urban Travel Destination. Bastie, J. a. (1991). La Ville. Paris: Masson Ed.

Bourne, L. S. (1971). Internal Structure Of The City. New York: Oxford University Press.

Fandeli, C. (1995). Dasar-Dasar Manajemen Kepariwisataan Alam. Yogyakarta: Penerbit Liberty.

Harianto, S. P. (1999). Konservasi mangrove dan potensi pencemaran . Jurnal Managemen \& Kualitas Lingkungan, Volume 1.

Rachmadanti, R. d. (2013). Penerapan Prinsip Adaptasi pada Desain Bangunan Ekowisata di Lahan Konservasi Mangrove Wonorejo. Jurnal Sains dan Seni Pomits Vol. 2 .

Satria, D. (May 2009). Strategi Pengembangan Ekowisata Berbasis Ekonomi Lokal dalam Rangka Program Pengentasan Kemiskinan di Kabupaten Malang. Journal of Indonesian Applied Economics Vol. 3.

Santoso, U. (2007). Permasalahan dan solusi pengelolaan lingkungan hidup di Propinsi Bengkulu . Jurnal Perhutani, Volume 2.

Saparinto, C. (2007). Pendayagunaan Ekosistem Mangrove. Semarang: Dahara Prize.

Schwanke, D. (2003). Mixed Use Development Handbook. Washington DC: Urban Land Institute.

Setyawan, A. I. (2004). Pencemaran logam berat $\mathrm{Fe}, \mathrm{Cd}, \mathrm{Cr}$, dan Pb pada Lingkungan Mangrove.

Setyawan, A. I. (2005). Tumbuhan mangrove di pesisir Jawa Tengah : 1. Keanekaragaman jenis. Biodiversitas.

Setyawan, A. I. (2005). Tumbuhan mangrove di pesisir Jawa Tengah : 2. Komposisi dan Struktur Vegetasi. Biodiversitas. 